\title{
DAMPAK INDUSTRI PT. GLOBAL COCONUT TERHADAP MASYARAKAT DI DESA RADEY, KECAMATAN TENGA, KABUPATEN MINAHASA SELATAN
}

\author{
Andreas Rasu \\ Noortje Marsellanie Benu \\ Elsje Pauline Manginsela
}

\begin{abstract}
The purpose of this study to determine the impact of the presence of Coconut Flour Industry (PT. Global Coconut) to the community in the Radey Village. This research was carried out on members of the village community Radey as respondents. Total respondents 32 people consisting of workers in the industry (25 persons), who did not work in the industry that ordinary members of community (5 persons) and community leaders (2 persons). The study lasted for 3 months from September to November 2016. The sample selection using snowballing method. Types of data collected in this study are primary and secondary data. Primary data is data obtained by direct interview to the respondents. Secondary data is obtained from the Village Office. The data collected concerning Identity Respondents, namely: (1) Name of Respondent, (2) age, expressed in units of years, (3) Level of education, measured by educational level already attained (elementary, junior high, high school, diploma, and University). Data regarding positive or negative impact of the presence of Industry on the community in the village of Radey regarding: (1) Income received before and after working in the company, (2) employment opportunities, (3) business opportunities. The analytical method used in this research is descriptive analysis method qualitative and quantitative modest presented in tabular form. The results of this research showed that the presence of PT Global Agro-Industry Plant in the Radey Village has gave positive and negative impacts for rural communities in the form of increases in income, employment and business opportunity, the new procurement of agricultural roads better and their support for the national celebration activities in the village. The negative impact of such a foul odor had happened only when the management of the rest of the selection in the form of broken coconut and waste production is not done well.
\end{abstract}

Keywords: impact, agro-industry, community, village Radey, South Minahasa District

\section{ABSTRAK}

Tujuan penelitian ini untuk mengetahui dampak keberadaan Industri Tepung Kelapa (PT. Global Coconut) terhadap masyarakat di Desa Radey. Penelitian ini dilakukan pada anggota masyarakat Desa Radey sebagai responden. Total responden 32 orang yang terdiri atas pekerja di Industri ( 25 orang), yang tidak bekerja di Industri yaitu anggota masyarakat biasa ( 5 orang) dan tokoh masyarakat ( 2 orang). Penelitian ini berlangsung selama 3 bulan yaitu dari bulan September sampai November 2016. Penentuan sampel responden menggunakan metode snowballing. Jenis data yang dikumpulkan dalam penelitian ini adalah data primer dan sekunder. Data primer yaitu data yang diperoleh dengan melakukan wawancara langsung kepada responden. Data sekunder yaitu data yang bersumber dari Kantor Desa. Adapun data yang dikumpulkan menyangkut Identitas Responden, yaitu: (1) Nama Responden, (2) Umur, dinyatakan dengan satuan tahun, (3) Tingkat pendidikan, diukur menurut tingkatan pendidikan yang sudah ditamatkan (SD, SMP, SMA, Diploma, dan Universitas). Data dampak positif atau negatif dari kehadiran Industri terhadap masyarakat di Desa Radey menyangkut: (1) Pendapatan yang diterima responden sebelum dan sesudah bekerja di perusahaan, (2) Peluang kerja, dan (3) Peluang berusaha. Metode analisis yang digunakan dalam penelitian ini adalah metode analisis deskriptif kualitatif dan kuatitatif sederhana yang disajikan dalam bentuk tabel. Hasil penelitian menunjukkan bahwa keberadaan Pabrik Agroindustri PT Global Coconut di Desa Radey memberikan dampak positif maupun negatif bagi masyarakat desa. Dampak positif berupa peningkatan pendapatan, tersedianya kesempatan bekerja dan peluang berusaha. Yang baru, pengadaan jalan pertanian yang lebih baik dan adanya bantuan untuk kegiatan perayaan nasional di desa. Dampak negatif berupa bau busuk pernah terjadi hanya pada saat pengelolaan tidak dilakukan dengan baik pada sisa seleksi dari proses produksi berupa kelapa pecah dan pada limbah hasil produksi

Kata kunci: dampak, agroindustri, masyarakat, Desa Radey, Kabupaten Minahasa Selatan 


\section{PENDAHULUAN}

Industri, termasuk agroindustri, merupakan salah satu sektor yang memiliki peranan penting dalam pembangunan suatu wilayah dan peningkatan pendapatan masyarakat. Pembangunan ekonomi antara lain melalui industri di suatu Negara dalam periode jangka panjang akan membawa perubahan mendasar dalam struktur ekonomi negara tersebut maupun masyarakatnya, yaitu perubahan dari ekonomi tradisional yang dititik beratkan pada sektor pertanian ke ekonomi modern yang didominasi oleh sektor industri (Tambunan, 2001).

Dari sudut pandang pemerintah, industrialisasi sering dianggap sebagai pintu masuk untuk membawa masyarakat ke arah kemakmuran, paling tidak sebagai motor penggerak dalam pembangunan ekonomi (Rahardjo, 1986). Oleh karena itu, industri menjadi perhatian pemerintah. Hal tersebut juga menjadi perhatian pemerintah daerah untuk melakukan pengembangan ekonomi. Hal ini tentunya sejalan dengan diberlakukannya Undang-Undang Nomor 32 Tahun 2004 tentang Pemerintah Daerah dan Undang-Undang Nomor 34 Tahun Perimbangan Keuangan antara Pusat dan Daerah. Kehadiran kedua Undang- Undang Desentralisasi tersebut memiliki pengaruh kuat dalam mengubah kegiatan pembangunan dan peningkatan ekonomi di daerah (Gandi, 2011). Industrialisasi merupakan mesin penggerak pertumbuhan ekonomi (Todaro dan Smith 2006), oleh karena itu strategi industrialisasi sering digunakan untuk meningkatkan kesejahteraan. Sektor industri pengolahan di Indonesia merupakan leading sector sejak Tahun 1990 (Wicaksono, 2009). Proses Industrialisasi berpengaruh lebih luas lagi yaitu membawa gejala ekonomi, berupa perkembangan infrastruktur dan perdagangan dengan proses kapitalisasi (akumulasi dan konsentrasi modal), persaingan ekonomi, gejala sosial berupa demokratisasi dan pertentangan kelas, serta gejala budaya berupa timbulnya gaya hidup yang produktif dan konsumtif, persepsi yang rasional, antisipatif dan pragmatis. Akibatnya hubungan antar manusia (human relations) menjadi berubah, demikian juga struktur sosial masyarakat di sekitarnya (Rahardjo, 1984). Industrialisasi yang semula berupa sebuah sistem yang diterapkan dalam usaha-usaha produksi pabrik, kemudian mempengaruhi komunitas secara keseluruhan.
Dengan demikian industri telah menciptakan pola kerja baru sebagai suatu model kerja yang belum pernah ada sebelumnya, dan kini merupakan gejala baru dalam tata kerja dan profesi yang spesifik (Sunarjan, 1991). Dengan demikian, terjadi pula perubahan distribusi pendapatan masyarakat antara sebelum dan sesudah masuknya Industri ke desa.

Keberadaan industri di suatu daerah dalam skala industri besar maupun skala industri kecil akan memberi pengaruh dan membawa perubahan terhadap kondisi sosial ekonomi masyarakat sekitarnya. Sebagaimana dikemukakan oleh (Singgih, 1991), bahwa dengan dibukanya lapangan pekerjaan pada suatu industri yang besar sifatnya mengakibatkan terbentuknya kesempatan baru, baik yang langsung diakibatkan oleh industri, misalnya terbukanya kesempatan kerja baru, bagi anggota masyarakat sekitar dan akibat lain yang bersifat langsung misalnya, kesempatan dalam usaha-usaha ekonomi bebas, usaha-usaha ekonomi bebas adalah merupakan usaha yang langsung memenuhi kebutuhan industri. Sedangkan keberadaan Industri di suatu wilayah akan mempengaruhi masyarakat, sebagaimana menurut (Parker dkk 1992), bahwa pengaruh industri terhadap masyarakat berupa nilai-nilai, pengaruh fisik terhadap masyarakat .

Berdasarkan penelitian terdahulu kehadiran industri (agroindustri), memberikan dampak baik positif maupun negatif bagi masyarakat sekitar. Hal ini menjadi dasar pertimbangan untuk mengadakan penelitian studi tentang dampak keberadaan PT Global Coconut terhadap masyarakat di Desa Radey Kecamatan Tenga Kabupaten Minahasa Selatan.

\section{Masalah Penelitian} berikut:

Masalah penelitian dirumuskan sebagai

Apa dampak dari keberadaan industri terhadap masyarakat Desa Radey?

\section{Tujuan Penelitian}

Berdasarkan permasalahan di atas, maka tujuan penelitian ini adalah mengetahui dampak keberadaan industri terhadap masyarakat di Desa Radey. 


\section{Kegunaan Penelitian}

Hasil penelitian ini diharapkan dapat memberi manfaat bagi para pihak yang terkait dengan dampak industri di desa Radey khususnya kepada:

1. Peneliti dan civitas akademikam

Penelitian ini merupakan proses belajar bagi peneliti dalam menganalisis dampak kehadiran industri terhadap masyarakat di Desa Radey.

\section{METODE PENELITIAN}

\section{Lokasi dan Waktu Penelitian}

Penelitian ini dilakukan pada anggota masyarakat Desa Radey baik yang bekerja di Industri Tepung Kelapa (PT. Global Coconut) maupun yang tidak. Desa Radey merupakan salah satu desa yang ada di Kecamatan Tenga, Kabupaten Minahasa Selatan. Penelitian ini berlangsung selama 3 bulan yaitu dari bulan September sampai November 2016.

\section{Metode Pengambilan Sampel}

Pekerja agroindustri khususnya masyarakat desa Radey secara keseluruhan berjumlah 60 orang. Dan yang menjadi responden terdiri dari 32 orang dibedakan 25 pekerja industri, bukan pekerja industri 5 responden masyarakat sekitar, 2 responden informan kunci yaitu sekertaris desa dan mantan kepala desa) . Penentuan sampel responden 25 pekerja industri menggunakan metode snowballing. Sedangkan 5 responden yang bukan pekerja penentuan sampel secara purposive yang tinggal di sekitar pabrik dimana 4 responden relatif tinggal di dekat dan 1 responden jauh dari lokasi pabrik. Dua orang informan kunci yaitu Mantan Kepala Desa, Sekretaris Desa Radey untuk mendapatkan informasi menyangkut masyarakt desa secara keseluruhan. Dengan demikian toral responden yang bukan pekerja industri sebanyak 7 responden masyarakat sekitar.

\section{Jenis Data dan Sumber Data}

Jenis data yang dikumpulkan dalam penelitian ini adalah data primer dan sekunder. Data primer yaitu data yang diperoleh dengan melakukan wawancara langsung kepada responden dalam hal ini pekerja PT Global Coconut dan anggota masyarakat tidak bekerja di industri serta informan kunci. Data sekunder yaitu data yang bersumber dari Kantor Desa.

\section{Data yang dikumpulkan}

\section{Identitas Responden}

1. Nama Responden

2. Umur, dinyatakan dengan satuan tahun

3.Tingkat pendidikan, diukur menurut tingkatan pendidikan yang sudah ditamatkan (SD, SMP, SMA, Diploma, Universitas)

\section{Variabel Penelitian}

Sumber data untuk mengetahui dampak industri terhadap masyarakat di Desa Radey yang adalah pekerja perusahaan tepung kelapa sebagai responden dan tokoh masyarakat sebagai informan kunci. Data yang dikumpulkan berdasarkan pertanyaan yang akan diajukan sesuai dengan tujuan penelitian menyangkut dampak positif, yaitu sebagai berkut:

1. Pendapatan yang diterima responden di perusahaan (dalam Rupiah).

2. Peluang kerja yang tercipta setelah industri beroperasi

3. Peluang berusaha yang tercipta setelah bekerja di industri

Pertanyaan yang menyangkut dampak negatif setelah kehadiran industri:

1. Kerugian sebelum proses produksi

2. Kerugian setelah proses produksi

\section{Metode Analisis Data}

Metode analisis yang digunakan dalam penelitian ini adalah metode analisis deskriptif kualitatif dan kuatitatif sederhana yang disajikan dalam bentuk tabel.

\section{HASIL DAN PEMBAHASAN}

\section{Profil Desa Radey}

Dalam penelitian ini pembahasan profil desa yang menggambarkan tentang keadaan atau kondisi dibatasi pada letak geografi dan batas-batas wilayah, penduduk menurut jenis kelamin, penduduk menurut tingkat pendidikan, penduduk berdasarkan mata pencaharian dan penduduk berdasarkan agama.

\section{Letak Geografi dan Batas-batas Wilayah}

Desa Radey memiliki jarak dengan ibukota kecamatan 2 kilometer (Desa Tenga), jarak dengan ibukota kabupaten (Kota Amurang) 20 kilometer, dan jarak dengan 
ibukota provinsi (Kota Manado) 650 kilometer. Desa Radey memiliki luas sekitar 826 hektar yang terdiri atas 4 jaga. Batas wilayah administratif Desa Radey sebagai berikut :

- Sebelah Utara berbatasan dengan Desa Molinow

- Sebelah Timur berbatasan dengan Desa Tenga

- Sebelah Selatan berbatasan dengan Desa Tawaang Barat

- Sebelah Barat berbatasan dengan Desa Tenga

\section{Penduduk menurut Jenis Kelamin}

Pembedaan masyarakat berdasarkan jenis kelamin menjelaskan tentang keadaan jumlah jiwa laki-laki dan perempuan yang ada di Desa Radey. Penduduk Desa Radey menurut jenis kelamin dapat dilihat pada Tabel 1.

Data pada Tabel 1. menunjukan bahwa penduduk laki-laki (905 jiwa) lebih banyak dari pada penduduk perempuan (714 jiwa), dimana Sex Ratio (SR)-nya sebesar 137. Artinya terdapat penduduk laki-laki (137 orang) lebih besar, untuk setiap 100 orang penduduk perempuan. Hal ini terjadi karena di Desa Radey tersedia peluang kerja.

\section{Penduduk menurut Tingkat Pendidikan}

Penduduk menurut pendidikan menjelaskan tentang bagaimana pencapaian tingkat pendidikan masyarakat di desa tersebut. Penduduk Desa Radey dapat menamatkan pendidikan dari tingkat Sekolah Dasar (SD), sampai tingkat Sekolah Menengah Atas (SMA), bahkan ada yang telah mengenyam pendidikan Perguruan Tinggi (S1, S2 dan S3). Tingkat pendidikan dari Penduduk di Desa Radey dapat dilihat pada Tabel 2.

Penduduk terbanyak adalah tamatan Sekolah Menengah Pertama (SMP) sebanyak 318 orang atau $41 \%$. Sedangkan Tamatan
Perguruan Tinggi (D2, D3, S1, S2, S3) sebanyak 41 orang atau 5,37\%. Bahkan sudah ada yang menamatkan Pendidikan S3 (satu orang). Kecuali lulusan SD dan lulusan S1, terdapat kecenderungan yaitu semakin tinggi tingkat pendidikan semakin sedikit jumlah orang yang dapat menamatkannya.

\section{Penduduk menurut Mata Pencaharian}

Penduduk menurut mata pencaharian menjelaskan mengenai jenis-jenis mata pencaharian yang tersedia di Desa Radey dan jumlah Kepala Keluarga (KK) yang bekerja di mata pencaharian tersebut. Jenis-jenis mata pencaharian ini merupakan sumber pendapatan penduduk. Penduduk Desa Radey menurut mata pencaharian dapat dilihat pada Tabel 3 .

Tabel 3 menunjukkan bahwa sebagian besar KK di Desa Radey bekerja di bidang pertanian $(46,50 \%)$ disusul oleh pegawai swasta, pengusaha kuliner, pekerja di bidang transportasi. Sedangkan jenis pekerjaan tersedikit adalah sebagai tukang anyaman adalah yang terendah (1 KK).

\section{Penduduk berdasarkan Agama dan Kondisi Sarana Ibadah}

Penduduk berdasarkan agama dan kondisi sarana ibadah merujuk pada keagamaan di desa tersebut dengan menjelaskan tentang agama apa saja yang ada di Desa Radey. Berikut ini menjelaskan penduduk berdasarkan agama.

\section{Penduduk berdasarkan Agama}

Penduduk menurut agama menjelaskan tentang penduduk menurut keagamaan yang ada di Desa Radey. Penduduk Desa Radey menurut agama dapat dilihat pada Tabel 4.

Data pada Tabel 4 menunjukan bahwa sebagian besar penduduk memeluk agama Kristen $(97,65 \%)$ yang terdiri dari $86 \%$ Kristen Protestan dan Kristen Katholik 11,55\%. Sedangkan non-kristen (Islam) sebesar 2,34\%.

Tabel 1. Penduduk menurut Jenis Kelamin di Desa Radey

\begin{tabular}{cccc}
\hline No. & Jenis Kelamin & Jumlah Jiwa & Persen (\%) \\
\hline 1 & Laki- laki & 905 & 55,90 \\
2 & Perempuan & 714 & 44,10 \\
\hline Jumlah & & 1619 & 100 \\
\hline
\end{tabular}

Sumber : Kantor Desa Radey, 2016 
Tabel 2. Jumlah Penduduk Menurut Tingkat Pendidikan di Desa Radey

\begin{tabular}{ccc}
\hline Pendidikan & Jumlah & $\cdot$ \\
\hline SD & 126 & Persen $(\%)$ \\
SMP & 318 & $16,51 \%$ \\
SMA & 278 & $41,67 \%$ \\
Diploma & 10 & $36,43 \%$ \\
S1 & 28 & $1,30 \%$ \\
S2 & 2 & $3,66 \%$ \\
S3 & 1 & $0,26 \%$ \\
Jumlah & 763 & $0,13 \%$ \\
\hline
\end{tabular}

Sumber : Profil Desa Radey, 2016

Tabel 3. Penduduk Menurut Mata Pencaharian Kepala Keluarga (KK) di Desa Radey

\begin{tabular}{lcc}
\hline Mata Pencaharian & Jumlah & Persen \\
\hline Petani & 380 & 46,50 \\
Buruh Batu-Bata & 120 & 15,00 \\
Ojek & 36 & 4,50 \\
Karyawan perusahaan Swasta & 60 & 7,50 \\
Karyawan perusahaan pemerintah & 2 & 0,25 \\
Pemilik usaha jasa transportasi dan perhubungan & 13 & 1,50 \\
Buruh usaha jasa transportasi dan perhubungan & 24 & 3,00 \\
Pemilik usaha warung ,rumah makan dan restoran & 41 & 5,13 \\
Pegawai Negeri Sipil & 24 & 3,00 \\
TNI & 3 & 0,38 \\
POLRI & 8 & 1,00 \\
Dokter swasta & 1 & 0,13 \\
Perawat swasta & 6 & 0,75 \\
Guru swasta & 7 & 0,88 \\
Pensiunan PNS,TNI & 12 & 1,50 \\
Sopir & 30 & 3,75 \\
Montir & 3 & 0,38 \\
Tukang kayu & 6 & 0,75 \\
Tukang sumur & 4 & 0,50 \\
Tukang jahit & 4 & 0,50 \\
Tukang kue & 24 & 3,00 \\
Tukang anyaman & 1 & 0,13 \\
\hline \multicolumn{1}{c}{ Total } & $\mathbf{8 0 0}$ & $\mathbf{1 0 0}$ \\
\hline
\end{tabular}

Sumber: Kantor Desa Radey, 2016

Tabel 4. Penduduk menurut Agama di Desa Radey, 2016

\begin{tabular}{clcc}
\hline No & Agama & Jumlah & Persen $(\%)$ \\
\hline 1 & Kristen Protestan & 1.394 & $86,10 \%$ \\
2 & Katholik & 187 & $11,55 \%$ \\
3 & Islam & 38 & $2,34 \%$ \\
\hline Jumlah & & 1.619 & 100,00 \\
\hline
\end{tabular}

Sumber : Kantor Desa,Radey 2015 


\section{Kondisi Sarana Ibadah}

Desa Radey memiliki Lima buah Gereja, yang terdiri dari Gereja Protestan, Pantekosta, Bala Keselamatan, Khatolik dan Advent. Hal ini sesuai dengan data penduduk yang hampir 98\% masyarakat di Desa Radey penganut agama Kristen. Walaupun terdapat penduduk 38 orang

berbeda keyakinan, mereka tetap hidup saling menghormati serta menghargai dalam menjalankan ibadah masing-masing.

\section{Gambaran Umum Industri PT. Global Coconut}

Industri PT. Global Coconut mulai berdiri pada tahun 2012 dan perusahaan mulai beroperasi pada tahun 2013. Industri PT. Global Coconut yang terletak di Desa Radey memiliki luas lahan lokasi industri sebesar 2,5 hektar dan 1,1 hektar perumahan industri jadi total 3,6 ha.

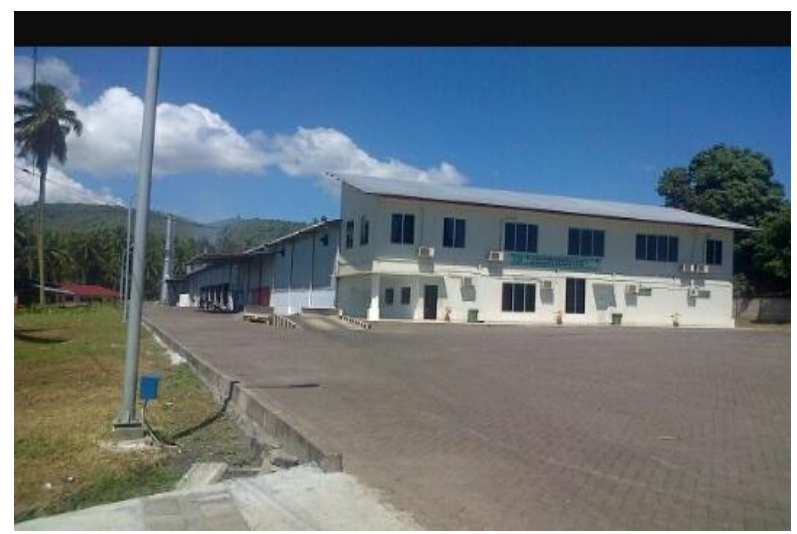

Gambar 1. Kawasan Industri

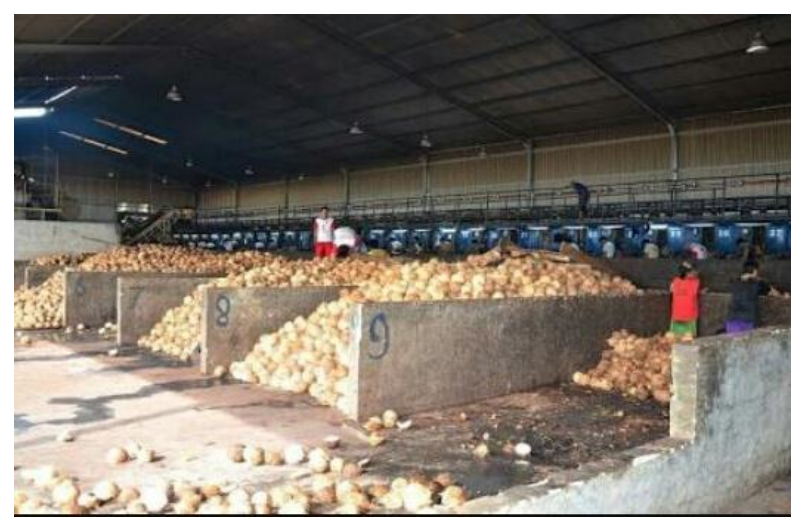

Gambar 2. Bodega (Opening)

Gambar 2. Adalah gambar dari area bodega. Bodega adalah tempat penampung kelapa setelah dimasuk dari para pemasok, lalu disortir atau memilih kelapa yang bagus atau kelapa yang tidak terbelah.

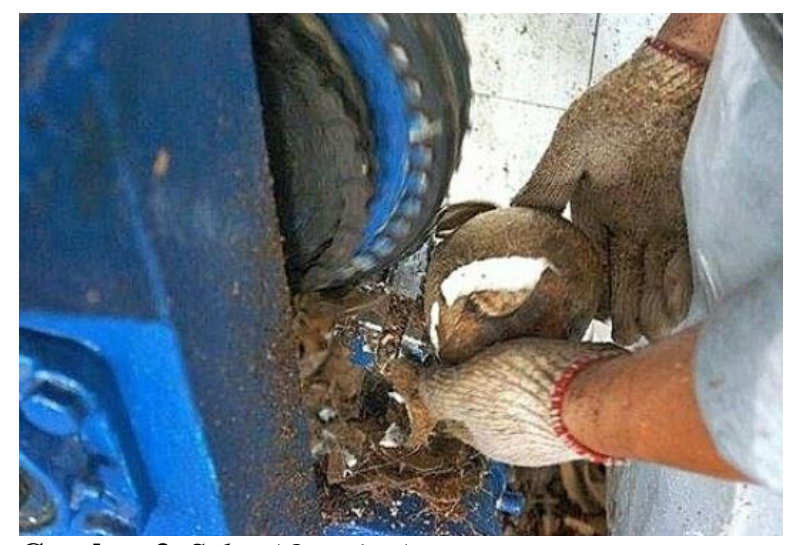

Gambar 3. Seler (Opening)

Gambar 3. Menunjukan bahwa dibagian seler adalah tahap dimana alat ini berfungsi untuk memisahkan daging kelapa dari tempurung.

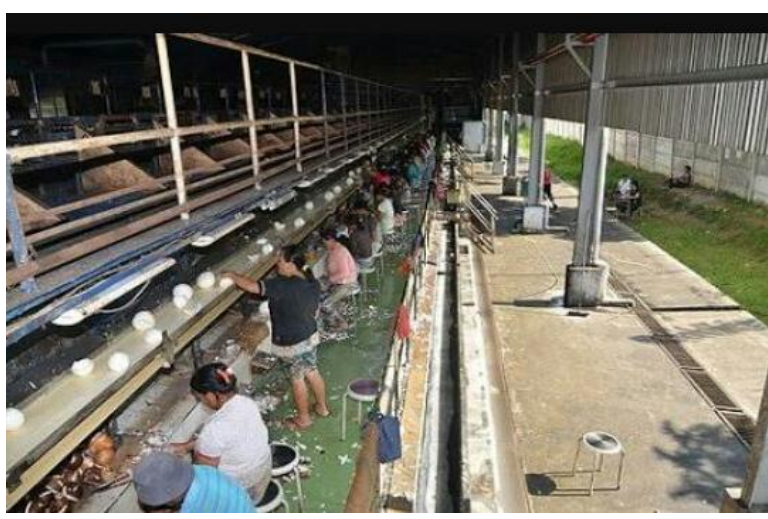

Gambar 4. Perer (Opening)

Gambar 4. Menunjukan bahwa dibagian Perer adalah tahap untuk memisahkan daging kelapa dari kulit ari.

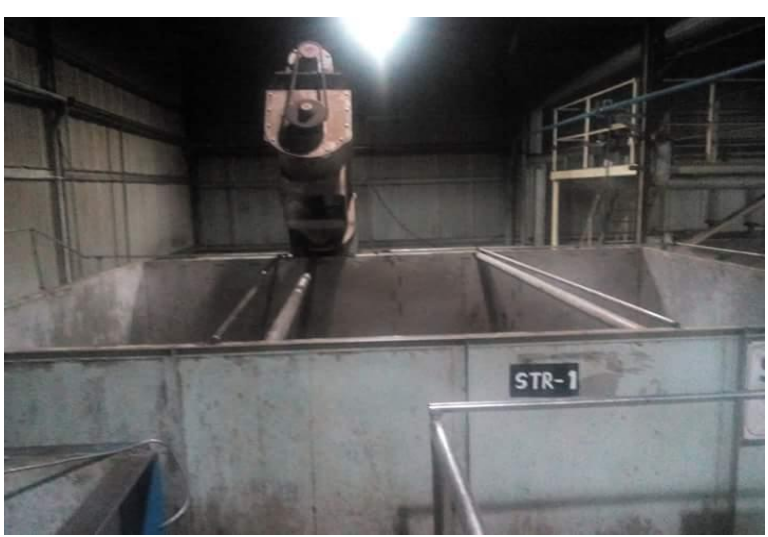

Gambar 5. Treatment (Processing)

Gambar 5. Menunjukan bahwa dibagian Treatment fungsinya adalah perawatan agar daging kelapa tetap utuh. 


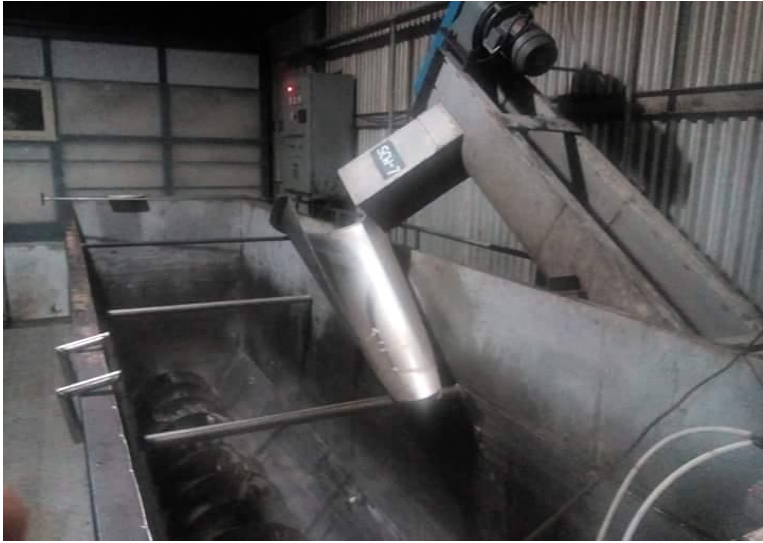

Gambar 6. Washing (Processing)

Gambar 6. Menunjukan bahwa dibagian Washing fungsinya adalah pencucian daging kelapa dengan air .

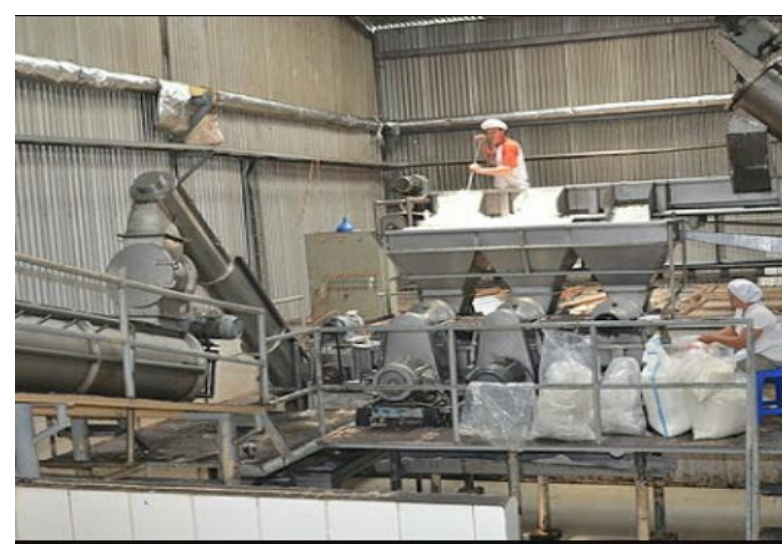

Gambar 7. Grinnder (Processing)

Gambar 7. Menunjukan bahwa dibagian Grinnder fungsinya adalah penggilingan daging kelapa.

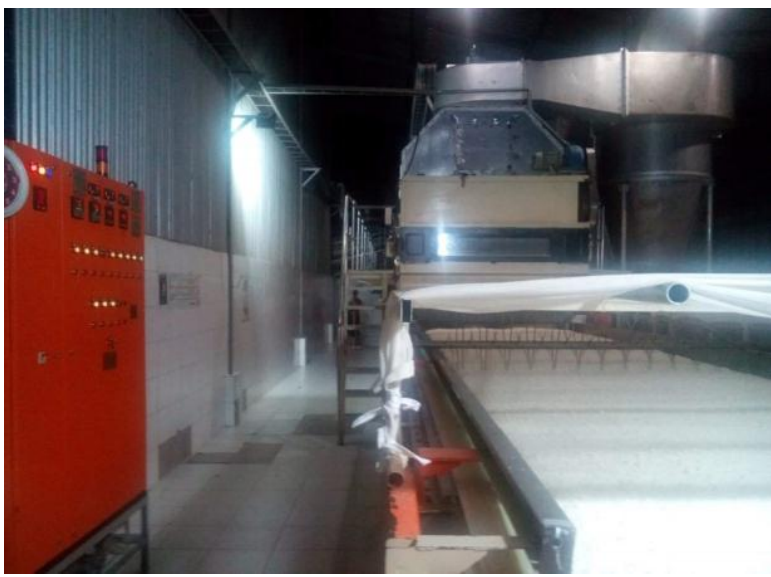

Gambar 8. Driyer (Processing)

Gambar 8. Menunjukan bahwa dibagian Dryer fungsinya adalah pengeringan.

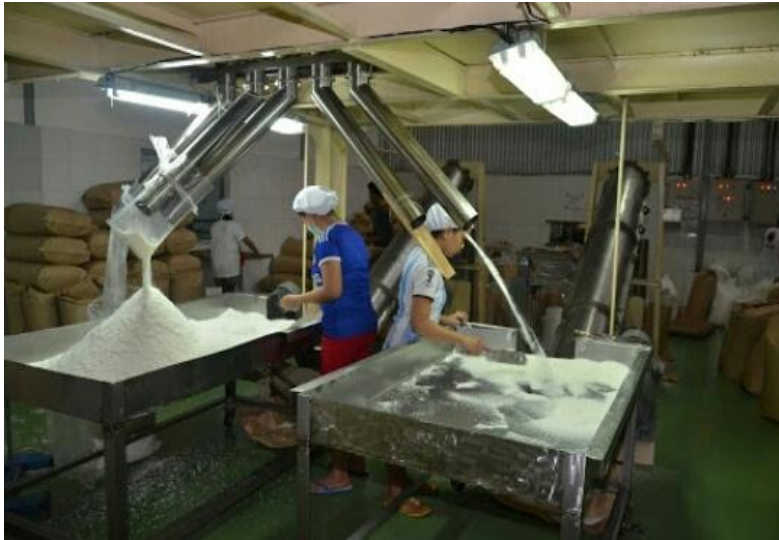

Gambar 9. Meja Piker (Processing)

Gambar 9. Menunjukan bahwa dibagian meja piker fungsinya adalah mengangkat kotoran hitam.

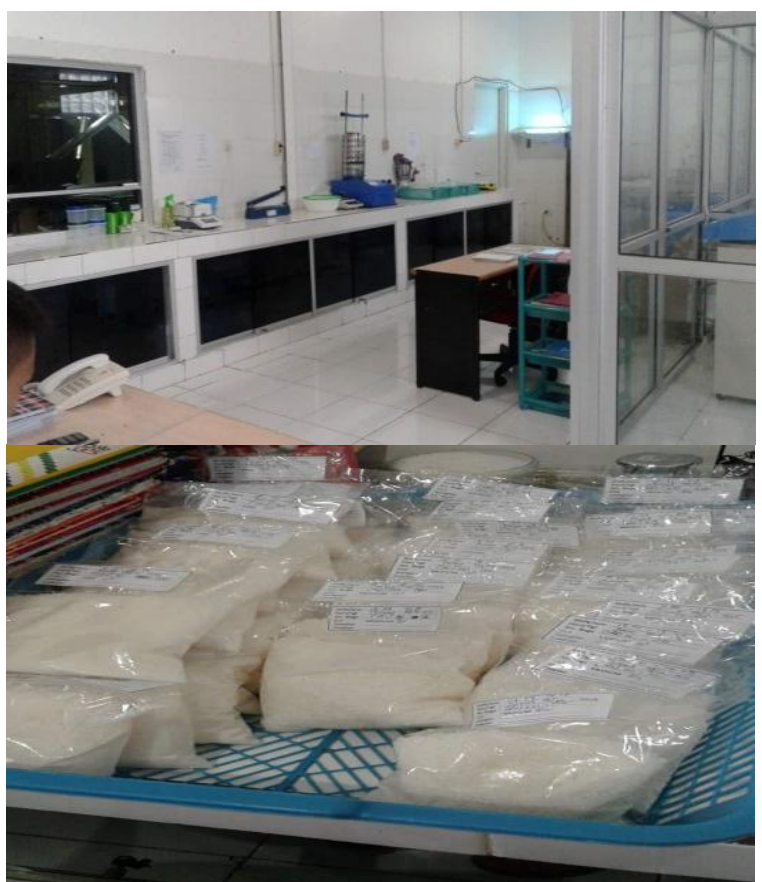

Gambar 10. Laboratorium (Processing)

Gambar 10. Laboratorium adalah bagian yang bertugas untuk pengendalian kualitas (quality control) tepung kelapa.

\section{Gambaran Responden}

Dalam penelitian ini, Responden dibedakan antara pekerja industri, bukan pekerja dan tokoh masyarakat (informan kunci). Uraian menyangkut gambaran Responden meliputi umur pekerja dan bukan pekerja, tingkat pendidikan pekerja dan bukan pekerja. 


\section{Umur Responden}

Umur responden menjelaskan tentang usia setiap responden yang terdiri dari pekerja, bukan pekerja dan dan tokoh masyarakat. Umur responden dapat dilihat pada Tabel 5.

Usia responden untuk usia 20-40 sebanyak 19 orang yang terdiri 16 orang pekerja dan 3 orang bukan pekerja (anggota masyarakat). Dan untuk umur antara 41-49 Tahun sebanyak 10 responden yang terdiri 7 orang pekerja, 1 orang anggota masyarakat dan 2 orang tokoh masyarakat. Sedangkan untuk umur $>49$ berjumlah 3 responden yang terdiri dari 2 orang pekerja dan 1 orang anggota masyarakat.

\section{Tingkat Pendidikan Responden Pekerja dan Bukan Pekerja Industri}

Tabel 6 menjelaskan atau menggambarkan tingkat pendidikan responden pekerja industri buruh maupun yang tidak bekerja di industry, dari tamat SD sampai dengan akademik (S 1/Diploma).
Berdasarkan hasil wawancara tingkat pendidikan responden Pekerja (10 orang), bukan pekerja ( 2 orang) dan tokoh masyarakat (1 orang) kebanyakan adalah tamat SMA. Dan tamatan tertinggi adalah S 1 (1 orang), sedangkan terendah SD (6 orang).

\section{Posisi Responden Sebagai Pekerja Industri}

Dalam penelitian ini yang dimaksud dengan posisi pekerja industri adalah pembedaan posisi pekerjaan berdasarkan sistim pemberian upah pekerja industri. Upah bulanan diterapkan kepada non-buruh (pengawas) sedangkan upah mingguan diterapkan kepada buruh industri. Pembedaan posisi responden sebagai pekerja industri dapat dilihat pada Tabel. 7.

Tabel 7 Menunjukan bahwa 13 responden pekerja laki-laki dan 9 responden pekerja industri adalah sebagai buruh. Sedangkan 3 responden pekerja industri sebagai non-buruh (pengawas) pada industri.

Tabel 5. Umur Responden

\begin{tabular}{cccccc}
\hline $\begin{array}{c}\text { Kelompok Umur } \\
\text { (Tahun) }\end{array}$ & $\begin{array}{c}\text { Pekerja } \\
\text { Industri }\end{array}$ & $\begin{array}{c}\text { Bukan } \\
\text { Pekerja }\end{array}$ & $\begin{array}{c}\text { Tokoh } \\
\text { Masyarakat }\end{array}$ & $\begin{array}{c}\text { Total } \\
\text { Responden }\end{array}$ & Persen \% \\
\hline $20-40$ & 16 & 3 & & 19 & 59 \\
$41-49$ & 7 & 1 & 2 & 10 & 31 \\
$>49$ & 2 & 1 & & 3 & 10 \\
\hline Jumlah & 13 & 5 & 2 & $\mathbf{3 2}$ & $\mathbf{1 0 0}$ \\
\hline
\end{tabular}

Sumber : Diolah dari Data Primer, 2016

Tabel 6. Tingkat Pendidikan Responden

\begin{tabular}{lccccc}
\hline \multicolumn{1}{c}{ Pendidikan } & $\begin{array}{c}\text { Pekerja } \\
\text { Industri }\end{array}$ & $\begin{array}{c}\text { Bukan } \\
\text { Pekerja }\end{array}$ & $\begin{array}{c}\text { Tokoh } \\
\text { Masyarakat }\end{array}$ & $\begin{array}{c}\text { Total } \\
\text { Responden }\end{array}$ & Persen \% \\
\hline S1/Diploma & 1 & - & 1 & 2 & 6 \\
SMA/SMK & 10 & 2 & 1 & 13 & 40 \\
SMP & 10 & 1 & - & 11 & 34 \\
SD & 4 & 2 & - & 6 & 20 \\
\hline \multicolumn{1}{c}{ Jumlah } & $\mathbf{2 5}$ & $\mathbf{5}$ & $\mathbf{2}$ & $\mathbf{3 2}$ & $\mathbf{1 0 0}$ \\
\hline
\end{tabular}

Sumber : Diolah dari Data Primer, 2016

Tabel 7. Pembedaan Posisi Pekerja Industri Buruh dan Non-Buruh

\begin{tabular}{ccccccc}
\hline $\begin{array}{c}\text { Pekerja } \\
\text { Industri }\end{array}$ & Laki-Laki & Persen (\%) & Perempuan & $\begin{array}{c}\text { Persen } \\
(\%)\end{array}$ & $\begin{array}{c}\text { Total } \\
\text { Responden }\end{array}$ & $\begin{array}{c}\text { Total } \\
\text { Persen }\end{array}$ \\
\hline $\begin{array}{c}\text { Buruh } \\
\text { (pon- Buruh }\end{array}$ & 13 & 82 & 9 & 100 & 22 & 88 \\
\hline Jumlah & 3 & 18 & - & & 3 & 12 \\
\hline
\end{tabular}

Sumber : Diolah dari Data Primer, 2016 


\section{Dampak Keberadaan Industri PT. Global Coconut}

Dalam penelitian ini dampak kehadiran Industri dibedakan menurut masyarakat sebagai pekerja maupun masyarakat yang tidak bekerja di industri. Menurut pekerja industry, kehadiran industri memberi dampak positif maupun negatif. Sedangkan menurut masyarakat yang bukan pekerja, tidak terdapat dampak negatif atas kehadiran industri. Berikut ini dampak kehadiran industri yang meliputi dampak positif dan negatif menurut pekerja industri dan dampak positif menurut bukan pekerja industri, yaitu sebagai berikut:

\section{Dampak Positif Keberadaan Industri PT. Global Coconut}

Dalam Penelitian ini Dampak Positif Keberadaan industri adalah dimana industri memberikan keuntungan bagi masyarakat Desa Radey dan masyarakat yang bekerja di industri tersebut.

\section{Dampak Positif Keberadaan Industri PT. Global Coconut Menurut Pekerja Industri}

Dalam penelitian ini yang dimaksud dampak positif adalah dimana kehadiran industri memberikan dampak yang menguntungkan bagi masyarakat Desa Radey, terlebih bagi anggota masyarakat yang bekerja di pabrik. Dampak positif meliputi peningkatan pendapatan sebelum bekerja di industri dari responden per bulan pendapatan rata-rata setiap pekerja per bulan pada tahun 2013-2015, dan pendapatan pekerja tahun 2016 dan hasil dari pekerjaan sampingan yang dimilki oleh sebagian pekerja industri. Berikut ini menjelaskan pendapatan pekerja sebelum bekerja di industri.

\section{Pendapatan Sebelum Responden bekerja pada Industri}

Pendapatan sebelum bekerja di Industri responden buruh dan non-buruh Industri. Pekerjaan sebelum pekerja industri terdiri dari buruh batu-bata, usaha batu-bata, ibu RT, karyawan toko, tukang jahit, buruh tani. Responden pekerja industri berdasarkan pendapatan sebelum dapat dilihat pada Tabel 8 .

Tabel 8 menunjukan pendapatan tertinggi dimiliki oleh pengusaha batu-bata sedangkan yang terendah ibu RT yang tidak memiliki penghasilan.

\section{Pendapatan Pekerja Industri}

Pendapatan responden pekerja industri pada bagian ini dibedakan atas dua kurun waktu yaitu tahun 2013-2015 dan tahun 2016. Hal ini dikarenakan pendapatan tahun 2013-2015, dimana pada tahun tersebut pendapatan pekerja industri adalah normal dikarenakan industri pada kondisi stabil yang disebabkan oleh bahan baku terpenuhi. Berikut ini pendapatan pekerja industri setiap pekerja per bulan pada tahun 2013-2015 dapat dilihat pada Tabel 9.

Tabel 9 menunjukan bahwa non-buruh industri sebanyak 3 responden menerima upah setiap pekerja per bulan pada tahun 2013-2015 sebesar Rp.3.500.000 dan pada tahun 2016 sebesar Rp.2.400.000. Dan pendapatan rata-rata per bulan dari 9 pekerja buruh perempuan (setiap pekerja) pada tahun 2013-2015 sebesar Rp. 2.300.000, dan pada tahun 2016 sebesar Rp.1.900.000 per bulan. Sedangkan untuk setiap buruh industri (13 pekerja) mendapatkan pendapatan per bulan pada tahun 2013-2015 sebesar Rp.3.800.000, dan pada tahun 2016 mendapatkan pendapatan Rp.1.900.000.

\section{Pekerjaan Sampingan Responden dari Pekerja Industri}

Berdasarkan hasil penelitian ditemukan beberapa responden pekerja industri sebagai buruh dan pengawas pada tahun 2016 memiliki pekerjaan sampingan. Ada 1 responden pekerja industri yang sebelum ia bekerja di industri sudah melakukan pekerjaan sebagai tukang jahit. Dua responden masing-masing bekerja bekerja sebagai tukang ojek dan beternak yang sebelumnya belum pernah dilakukan. Pekerjaan sampingan responden dapat dilihat pada Tabel. 10.

Tabel 10 menunjukan bahwa jumlah responden pekerja industri yang memiliki pekerjaan sampingan akibat penurunan jumlah shif yang tersedia, adalah 3 responden pekerja industri. Pekerjaan sampingan terdiri dari satu responden sebagai tukang jahit memiliki pendapatan perbulan Rp.1000.000, dan satu responden non-buruh industri bekerja sebagai tukang ojek, mendapatkan upah per bulan sebesar Rp.700.000. Sedangkan satu responden memiliki usaha ternak babi dengan pendapatan per bulan Rp.1.166.000. 
Tabel 8. Pendapatan per bulan Sebelum Responden Pekerja Industri

\begin{tabular}{lcccccc}
\hline \multicolumn{1}{c}{$\begin{array}{c}\text { Pekerjaan } \\
\text { Sebelumnya }\end{array}$} & \multicolumn{2}{c}{ Jenis Kelamin } & Pendapatan & \multicolumn{2}{c}{ Posisi di Industri } & Jumlah \\
\hline Buruh B.Bata & 9 & 2 & 1.545 .000 & 10 & 1 & 11 \\
Usaha B.Bata & 2 & - & 2.650 .000 & 2 & - & 2 \\
Ibu RT & - & 6 & - & 6 & - & 6 \\
K. Toko & 1 & 1 & 1.875 .000 & 2 & - & 2 \\
Tukang Jahit & 1 & - & 2.000 .000 & 1 & - & 1 \\
Buruh Tani & 3 & - & 1.600 .000 & 1 & 2 & 3 \\
\hline \multicolumn{1}{c}{ Jumlah } & $\mathbf{1 6}$ & $\mathbf{9}$ & $\mathbf{9 . 6 7 0 . 0 0 0}$ & $\mathbf{2 2}$ & $\mathbf{3}$ & $\mathbf{2 5}$ \\
\hline
\end{tabular}

Sumber : Diolah dari Data Primer, 2016

Tabel 9. Pendapatan Pekerja Industri Per bulan Per responden Tahun 2013-2015 dan 2016

\begin{tabular}{cccccccc}
\hline $\begin{array}{c}\text { Non-Buruh } \\
\text { L }\end{array}$ & P & L & P & $\begin{array}{c}\text { Total } \\
\text { Responden }\end{array}$ & $\begin{array}{c}\text { Pendapatan tahun } \\
2013-2015\end{array}$ & $\begin{array}{c}\text { Pendapatan } \\
\text { tahun 2016 }\end{array}$ \\
\hline 3 & - & - & - & 3 & 3.500 .000 & 2.400 .000 \\
& - & - & - & 9 & 9 & 2.300 .000 & 1.900 .000 \\
& - & - & 13 & - & 13 & 3.800 .000 & 1.900 .000 \\
\hline Jumlah & $\mathbf{3}$ & $\mathbf{0}$ & $\mathbf{1 3}$ & $\mathbf{9}$ & $\mathbf{2 5}$ & $\mathbf{9 . 6 0 0 . 0 0 0}$ & $\mathbf{6 . 2 0 0 . 0 0 0}$ \\
\hline
\end{tabular}

Sumber : Diolah dari Data Primer, 2016

Tabel 10. Pekerjaan Responden Sesudah bekerja Di Industri

\begin{tabular}{lcccccc}
\hline \multirow{2}{*}{$\begin{array}{c}\text { Pekerjaan } \\
\text { Sampingan }\end{array}$} & \multicolumn{2}{c}{ Lenis Kelamin } & & \multicolumn{2}{c}{ Posisi Di Industri } & Tpah/Bulan \\
& & Baki-Laki & Perempuan & Pengawas & Total \\
\hline Tukang Jahit & 1 & - & Rp.1.000.000 & 1 & - & 1 \\
Ojek & 1 & - & Rp.700.000 & - & 1 & 1 \\
Beternak & 1 & - & Rp.1.166.000 & 1 & & 1 \\
\hline \multicolumn{1}{c}{ Jumlah } & $\mathbf{3}$ & - & $\mathbf{1 . 7 0 0 . 0 0 0}$ & $\mathbf{2}$ & $\mathbf{1}$ & 3 \\
\hline
\end{tabular}

Sumber : Diolah dari Data Primer, 2016 


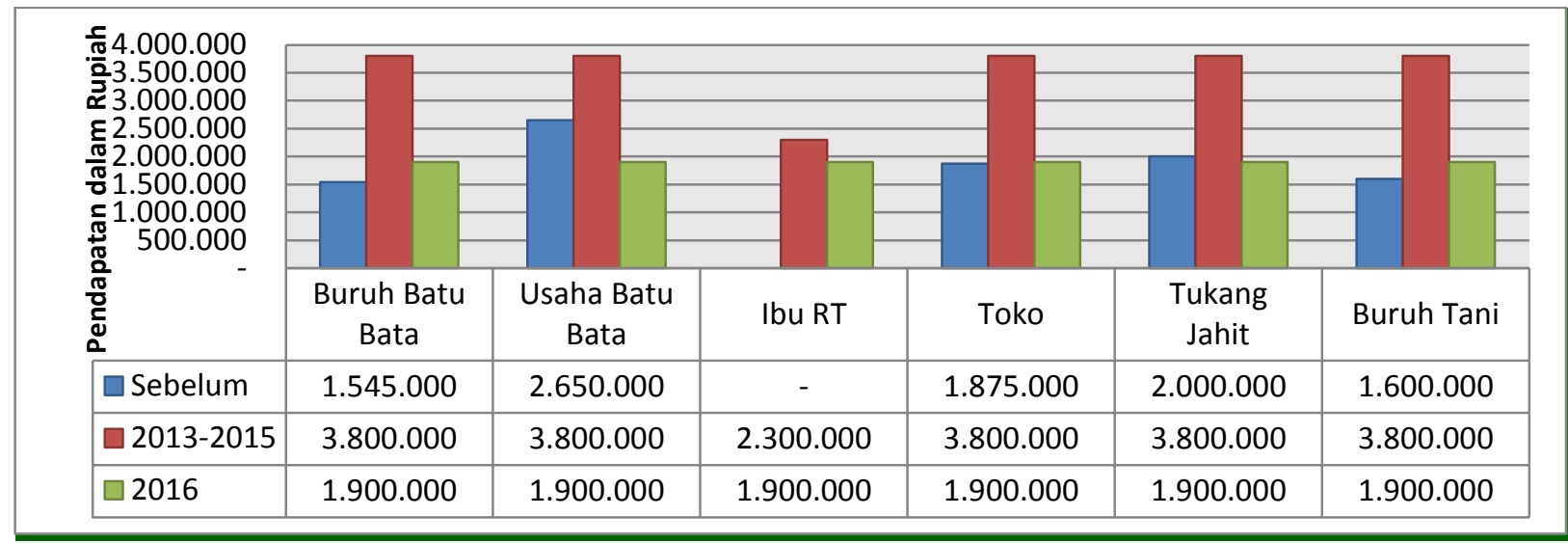

Gambar 11. Pendapatan rata-rata (Rp) pekerja per bulan per orang industri sebelum dan sesudah bekerja di industri

Gambar. 11 diatas menunjukan bahwa terjadinya penurunan bahan produksi yang telah menyebabkan penurunan pendapatan karena berkurangnya jam kerja (shift) pekerja pada tahun 2016 dibanding periode sebelumnya (2013-2015). Hal ini berdampak negatif pada buruh pabrik yang sebelumnya sebagai pengusaha batu-bata dan tukang jahit. Tetapi tetap memberikan dampak positif bagi buruh pabrik yang sebelumnya bekerja sebagai ibu rumah tangga, buruh batu bata, karyawan toko, dan buruh tani.

\section{Dampak Positif Kehadiran Industri Menurut Bukan Pekerja Industri}

Dampak dalam hal ini adalah dampak positif menurut masyarakat Desa Radey yang bukan pekerja industri.Kehadiran industri terhadap masyarakat Desa Radey. Dampak positif menurut responden yang bukan pekerja (masyarakat sekitar yang tinggal di dekat dan jauh dari pabrik) dan informan kunci yang adalah tokoh masyarakat.

Dampak positif dari adanya industri di Desa Radey, menurut mereka berupa tersedianya lapangan pekerjaan, peningkatan pendapatan, dan peluang berusaha, pengadaan jalan pertanian dan pemberianbantuan uang untuk kegiatan perayaan hari kemerdekaan. Menurut semua responden dampak positif bagi pekerja industri dalam hal ini adalah buruh dan non-buruh yang bekerja di industri dapat dilihat pada Tabel 11.

Tabel 11 menunjukan bahwa pendapat dari Lima responden masyarakat sekitar dan Dua responden informan kunci yaitu Sekertaris Desa Radey dan Mantan Kepala Desa Radey mengatakan bahwa kehadiran Industri telah membuka lapangan kerja bagi masyarakat, bahkan telah memiliki mata pencaharian tetap atau pendapatan tetap.

\section{Peluang Berusaha}

Berdasarkan wawancara ditemukan bahwa kehadiran Industri menciptakan peluang berusaha. Satu non-buruh industri dari upahnya ia dapat memiliki Ternak sapi. Ternak sapi tersebut dipercayakan kepada orang lain dengan sistim Tumoyo 1:3. Artinya bila ternak sapi itu memiliki anak tiga ekor sapi, maka pemilik sapi berhak memiliki 2 ekor anak sapi. Sedangkan pekerjanya mendapatkan 1 ekor anak sapi. Satu buruh Industri dari upah bekerja di Industri ia dapat membeli beberapa ekor babi untuk dibesarkan dan dijual kembali sebagai babi yang siap diolah menjadi babiputar. Sedangkan bagi tiga responden dari upah bekerja di industri mengumpulkan uang untuk memiliki rumah, Dua responden dari upah di industri dapat membiayai kuliah anaknya. Responden pertama dapat membiayai satu orang anak sedangkan responden kedua membiayai 2 orang anaknya. Responden kedua ini salah satu anaknya telah meraih gelar sarjana.

\section{Dampak Positif Kehadiran Industri Menurut Tokoh Masyarakat Kesempatan Bekerja}

Kehadiran industri telah memberikan kesempatan bekerja kepada seluruh masyarakat Desa Radey, karena dari pihak Industri membuat kesepakatan dengan Pemerintah Desa ( Kepala Desa ) bahwa setiap Keluarga dipekerjakan minimal 1 Anggota keluarga, bahkan lebih dari 1 anggota keluarga. 


\section{Pengadaan jalan pertanian dan bantuan untuk kegiatan perayaan}

Berdasarkan wawancara dampak kehadiran Industri berdampak pada masyarakat Desa Radey. Menurut Pemerintah Desa Radey dalam penelitian ini adalah Sekertaris Desa Radey ditemukan dampak pada masyarakat.

1. Pemberian tanah untuk jalan pertanian dengan lebar 4 Meter dan panjang 100 meter.

2. Bantuan berupa uang tunai sejumlah Rp.5.000.000 dalam menunjang kegiatan Tujuh Belas Agustus pada tahun 2015.

Dampak positif keberadaan pabrik bagi masyarakat Desa Radey adalah peningkatan pendapatan dan jaminan kekontinuannya, terciptanya peluang bekerja, peluang berusaha, Pengadaan jalan pertanian dan bantuan untuk kegiatan perayaan. Sedangkan dampak negatif adalah bau busuk dari kelapa hasil sordtiran dan dari hasil pengolahan tepung kelapa.

\section{Dampak Negatif Keberadaan Industri PT. Global Coconut}

Adapun Dampak Negatif Keberadaan Industri PT. Global Coconut menurut Pekerja Industri berdasarkan wawancara berupa bau limbah, serta bau kelapa busuk. Yang dimaksud bau limbah adalah hasil pengolahan limbah yang tidak maksimal, sedangkan bau kelapa busuk adalah hasi sortiran dari kelapa pecah (keterlambatan pembersihan). Dampak negatif yang dirasakan responden pekerja industri dapat dilihat pada Tabel 12 .

Tabel 12 menunjukkan bahwa 4 buruh Industri dan 1 non-buruh industri mengatakan adanya bau limbah. Sepuluh responden buruh Industri mengatakan bau kelapa busuk. Sedangkan 10 responden mengatakan tidak ada dampak negatif yang terdiri dari 8 responden buruh Industri dan 2 non-buruh Industri. Hal ini diduga, antara lain, karena tempat tinggal mereka jauh dari lokasi pabrik atau lokasi mereka tinggal tidak berdekatan dengan sumber bau.

Tabel 11. Dampak Positif Menurut Responden Anggota Masyarakat yang Tidak bekerja di Industri

\begin{tabular}{ccccc}
\hline Dampak positif & $\begin{array}{c}\text { Masyarakat } \\
\text { Sekitar }\end{array}$ & $\begin{array}{c}\text { Informan } \\
\text { Kunci }\end{array}$ & Total Responden & Persen(\%) \\
\hline $\begin{array}{c}\text { Lapangan pekerjaan } \\
\text { dan Pendapatan Tetap }\end{array}$ & 5 & 2 & 7 & 100 \\
\hline Jumlah & 5 & 2 & 32 & 100 \\
\hline
\end{tabular}

Sumber : Diolah dari Data Primer, 2016

Tabel 12. Dampak Negatif Buruh dan Non-Buruh di Industri

\begin{tabular}{lcccccc}
\hline \multirow{2}{*}{ Dampak Negatif } & $\begin{array}{c}\text { Buruh } \\
\text { Industri }\end{array}$ & $\begin{array}{c}\text { Persen } \\
(\%)\end{array}$ & $\begin{array}{c}\text { Non } \\
\text { buruh }\end{array}$ & $\begin{array}{c}\text { Persen } \\
(\%)\end{array}$ & \multicolumn{2}{c}{ Total Pekerja Industri } \\
\cline { 7 - 8 } & 4 & 20 & 1 & 34 & 5 & Jumlah \\
Limbah & 8 & 36 & 2 & 66 & 10 & Persen (\%) \\
Tidak Ada & 10 & 44 & - & - & 10 & 40 \\
Bau Busuk Kelapa & 22 & 100 & 3 & 100 & 25 & 100 \\
\hline Jumlah & & & & & &
\end{tabular}

Sumber : Diolah dari Data Primer, 2016

\section{KESIMPULAN DAN SARAN}

\section{Kesimpulan}

Keberadaan Agroindustri PT Global Coconut memberikan dampak postif dan negatif bagi masyarakat di Desa Radey baik sebagai pekerja, bukan pkerja dan tokoh masyarakat. Keberadaan Industri "PT Global Coconut" telah memberikan dampak positif berupa peningkatan pendapatan, tersedianya kesempatan bekerja dan peluang berusaha, pengadaan jalan pertanian dan adanya bantuan untuk kegiatan perayaan nasional di desa. Sedangkan dampak negatif adalah bau busuk dari kelapa hasil sortiran berupa kelapa busuk dan limbah dari hasil pengolahan tepung kelapa.

\section{Saran}

Bagi peneliti selanjutnya diharapkan dapat lebih menggali dampak positif dari keberadaan Industri di pedesaan bagi masyarakat Desa Radey. 


\section{DAFTAR PUSTAKA}

Farhani, A. 2009. Motivasi Sosial Ekonomi Petani Beralih Pekerjaan dari Sektor Pertanian ke Sektor Industri Kerajinan Mebel di Desa Serenan Kecamatan Juwiring Kabupaten Klaten. Surakarta: Disertasi, Universitas Sebelas Maret.

Felani, M., \& Hamzah, A. 2007. Fitoremediasi Limbah Cair Industri Tapioka Dengan Tanaman Eceng Gondok. Yogyakarta: Buana Sains, Universitas Gadjah Mada.

Gandi, R. 2011. Pengaruh Industrialisasi PeDesaan Terhadap Taraf Hidup Masyarakat Di RW 01 Dan RW 09 Desa Benda, Kecamatan Cicurug, Kabupaten Sukabumi, Provinsi Jawa Barat.

Ishijima H. 1997. New Perspective on Rural Industrialization. Tokyo: Report of an APO Seminar.

Maulida, A. 2015. Analisis Pengaruh Ukuran Perusahaan, Umur Perusahaan, Kepemilikan Public, Profibilitas, Dan Leverage Terhadap Tingkat Pengungkapan Intelectual Capital Pada Perusahaan Yang Terdaftar Di Jll Tahun 2012-2013. Uin Sunan Kalijaga Yogjakarta: Doctoral dissertation.

Muchni, H. 2008. Pengaruh Keberadaan PT. Pmks (Pabrik Minyak Kelapa Sawit Talikumain Terhadap Pengembangan Wilayah Di Kabupaten Rokan Hulu. Wahana Hijau.

Nawawi, I., Ruyadi, Y., \& Komariah, S. 2015. Pengaruh Keberadaan Industri Terhadap Kondisi Sosial Ekonomi Dan Budaya Masyarakat Desa Lagadar. Sosietas.

Prasetyawan A. W. 2010. Dampak Perkembangan Perkebunan The Tambi Terhadap Kehidupan Sosial Ekonomi Masyarakat Dusun Bedakah Tahun 1957-1998. Semarang: Disertasi, Universitas Negeri Semarang.

Rahardjo, M. D. 1984. Transformasi Industri Aliansi dan Kesempatan Kerja.
Rauf, A. W., \& Lestari, M. S. 2009. Pemanfaatan Komoditas Pangan Lokal Sebagai Sumber Pangan Alternatif Di Papua. Papua: Jurnal Litbang Pertanian.

Rusmawardi. 2007. Dampak Berdirinya Perkebunan Kelapa Sawit (Elaeis Guineensis Jack) terhadap Kondisi Sosial Ekonomi Masyarakat (Studi Kasus pada Desa Kabuau, Kecamatan Parenggean, Kabupaten Kota Waringin Timur, Propinsi Kalimantan Tengah. Diakses pada tgl 11 Februari 2015, pukul 19.26 wita.

Setyawati, E. A. 2002. Pengaruh Kegiatan Operasi Kawasan Industri Terhadap Perkembangan Sosial Ekonomi Masyarakat Pe-Desaan. Bogor: Disertasi, IPB.

Sinaga, B. M., \& Susilowati, S. H. 2007. Dampak kebijakan Ekonomi Di Sektor Agroindustri Terhadap Distribusi Pendapatan Sektoral, Tenaga Kerja Dan Rumah Tangga di Indonesia: Analisis Sistem Neraca Sosial Ekonomi. SOCA (Socio-Economic Of Agriculture And Gribusines).

Soedjito. 1960. Psikologi Pendidikan. Jakarta: Erlangga.

Soeharjo \& Patong. 1973. Sendi-sendi Pokok Ilmu Usaha Tani. Bogor: Departemen Ilmu-ilmu Sosial Ekonomi Fakultas Pertanian Institut Pertanian.

Statistik, B. P. 2000. Profil Industri Kecil dan Kerajinan Rumah Tangga. Jakarta: BPS.

Sumarwoto, O. 2009. Analisis Mengenai Dampak Lingkungan. Yogyakarta.

Syaifullah. 2009. Industrialisasi, Manusia Industri dan Perubahan Sosial. Jurnal Geografi GEA.

Tambunan, dkk. 2013. Kebijakan Industri dalam Menyongsong ME-ASEAN 2015. Policy Paper Edisi 16 April 2013. 
Tambunan, T. 2001. Industrialisasi di Negara Sedang Berkembang: Kasus Indonesia. Ghalia Indonesia.

Udayana, I. 2011. Peran Agroindustri dalam Pembangunan Pertanian. Jurnal Singhadwala, (44).

Utami, S. I. S. K. A. 2013. Analisa Efisiensi Produksi Pada Pabrik Pengolahan Kelapa Sawit di PT Gersido Minang Plantation Kecamatan Lingkung Aur Kabupaten Pasaman Barat. Padang: Universitas Andalas.
Wicaksono, R., \& Purwanti, E. Y. 2001. Analisis Pengaruh PDB Sektor Industri, Upah Riil, Suku Bunga Riil, dan Jumlah Unit Usaha Terhadap Penyerapan Tenaga Kerja pada Industri Pengolahan Sedang dan Besar di Indonesia Tahun 1990-2008. Semarang: Disertasi, Universitas Diponegoro. 